\title{
Folk Knowledge in Maintaining Group Integration and Socio-economic Intimacy among the Arsi-Robe Peasants
}

Yeshaw Tesema Yideg

Faculty of Languages and Humanities

Kotebe Metropolitan University

Ethiopia

fikareselaw@gmail.com

Yosef Beco Dubi

$\mathrm{Ph} . \mathrm{D}$

Faculty of Languages and Humanities

Kotebe Metropolitan University

Ethiopia

yosefbeco@gmail.com

\section{Abstract}

The purpose of this article is to analyze the folk knowledge in maintaining folk group integration and socio-economic intimacy among the Arsi-Robe peasants. The significance of folk knowledge in folklore of the society in connection with group integration and socioeconomic welfare is the case in point. This study employed a field survey research and data gathering method through the participant observation as well as direct interview. In order to obtain the substantial folkloristic data from local sources (people, occasions, or other settings), the researchers had familiarized with the social behavior and local environment of each locality. As far as the findings of this study are concerned, two points may be 
underscored here. People are customarily designated to take part in group-driven occupational habits like däbo and wänfä. Amongst the Arsi-Robe traditional society, if people isolate themselves from communal works, they are criticized, if not ostracized and excluded from the mainstream social and cultural roles. They also play their potential roles in kinship and kinship-like social relations. Put another way, they make interventions between their own world and a social unit in their vicinities according the collective paradigm set customarily.

Keywords: Folk knowledge, folk group, folklore, integration, dabo, wanfa, social welfare

Introduction

The human world is an essential and influential factor in the peasant environment of the area under study. This is because peasantry-based economic life is primarily concerned with the human world. Peasants' knowledge is constructed, developed and taught usually in a customary way (Sims and Stephen, 2005). Hence the human world is not only the origin of thought, mentality, planning, and practice, but also it is the leading stakeholder in the production process, as well obtaining the ultimate gain, from any form of yield. In addition, the human world is highly concerned with favorable or unfavorable forms of phenomena in the environment.

The human role is treated from its folkloric perspective. It is clear that, owing to its traditional peasantry nature, the human world in Arsi-Robe could have plenty of folklore wealth, which invites extensive as well as intensive exploration. But it is not easy to cover the whole spectrum of folklore stockpiles, concerned with the human world. Consequently, this study limited its scope to topics connected with the role of folklore in maintaining social intimacy and integration; and the significance of intimacy-nurturing-folklore in the peasantry. 
In recent years, people have tended to see folklore as an artwork that connotes only folksong or traditional music and dances. This assumption, however, lacks scientific justification according to some scholars like Dundes (cited in Bronner, 2008). More specifically, it may become difficult to class all folklore materials under the scope "oral literature", since it subsumes other forms which could not be communicated necessarily through spoken words. It could be also delivered or conveyed using materials or customary expressions, like the case in Arsi-Robe farmers' narratives. This implies that folklore embraces traditions, economic systems, forms of social organizations, customs, arts, etc., rather than a single genre, folk literature (Peck and Yankah, 2004).

Hence, it is the purpose of this study to address the gap in folklore study of the group under investigation and answer the following research questions.

- What are the knowledge practices embedded in the folklore of the Arsi-Robe peasants?

- How does the society harmonize themselves with their indigenous practices?

- What are the significances of folk knowledge in maintaining group integration and socio-economic intimacy?

\section{The Concept of Folk Knowledge and Folklore}

Scholars have not been able come to a consensus about the definition of the term folklore, though it is considered to be universal and to constitute features of folk knowledge everywhere (Bauman, 1992). This is so because: (1) its definition is affected by varied perspectives of different scholars (2) folklore could not be explained merely in a short definition as it constitutes wide-ranging as well as intricate human experiences. Viewing its definition from the current predispositions, therefore, the term folklore has received a wide- 
ranging attention which involves great varieties of locally created folk knowledge, collectively maintained and customarily passed on cultural heritages.

The homegrown knowledge and heritages comprise intellectual, material and physical wealth of a society including human values such as traditional arts, beliefs, occupational practices, entertainments, and festivals (Wilson, 2006). Referring to this position, Ben Botkin (cited in Suter, 1994) also writes that every group bound together or by common interests and purposes. Whether experienced or inexperienced, rural or urban, traditional societies possess a body of traditions in their, which may be called 'folklore'. Into these traditions enter many elements, individual, popular, and even 'literary,' but all are absorbed and assimilated through repetition and variation into a pattern, which has value and continuity for the group as a whole'.

Thus, the term has undergone changes in its history. According to Suter (1994) in some cases the terminology used to cover a narrower scope, is exclusively oral folklore. At other times its meaning was viewed as referring to mythological and legendary antiquities of a single nation, Greek. But today new perspectives are emerging and its scope is expanding. Even some scholars argue that in a purely oral culture everything is folklore (Wilson, 2006). Current scholarship appreciates that all human groups are guided by traditions that may have ancient or recent origins and folkloric by their very nature. In contemporary Africa, for example, traditions no longer 'depend exclusively on oral transmission but may be carried by any or all media, as demonstrated' in such forms as 'customs, salutations, gestures etc.' (Peck and Yankah 2004: x). In a similar vein, Sims and Stephens (2005:23) consider folklore to be the representation of "many kinds of informal communication, whether verbal (oral and written texts), customary (behaviors, rituals) or material (physical objects)'. In short, many scholars agree that the broader term folklore involves multifaceted values, traditions, ways of thinking and behaving. 
Sims and Stephens (2005), for example, confirm that folklore is informally learned, unofficial knowledge about the world, ourselves, our communities, our beliefs, our cultures and our traditions, that is expressed creatively through words, music, customs, actions, behaviors and materials. It is also the interactive, dynamic process of creating, communicating, and performing as we share that knowledge with other people'. Wilson (2006) implies that the concept of folklore applied to the study of aspects of rural peasant culture, this term has been extended to refer to other cultures and subcultures. The study of folklore embraces the examination of traditional knowledge, customs, oral and artistic traditions of any community (or section of a community) united by some common factors, such as common occupation, co-residence, a common language or ethnic identity (original brackets)'.

In the above context, the expressions 'pattern', 'continuity' 'occupation', 'customs', respectively, seem to be worth discussing to understand the concept of 'folklore' from its socio-economic perspective. The expressions bring into mind the struggle that happens to occur between human beings and varied forms of local challenges in the process of gaining means of survival and securing human welfare (Hedstrom and Swedberg, 1998). According to Fisher (1991), occupational as well as lifestyle patterns or forms of customs, for example, happen to emanate from frequently experienced human practices-they are results of recurring human activities. Fisher's view may be extended further. The components of experiences acquired through repetitions are essentially related to as well as operate on socio-economic institutions. The socio-economic institutions, on their part, are essentially characterized by multidimensional challenges. 
Methodology

The data collection was carried out considering Wilson (cited in Oring, 1992: 227) advices general guideline which he mentions as, "where to collect from, what to collect, how to collect, and how to write up your data' (emphasis added). The data was collected paying regular visits. Frequent contextual observations, interviews and discussions had been the nucleus of activities.

The fieldwork had also involved local people who served in the data collection and in interpreting texts. Both the author and the field work agents had attended gatherings, rituals, individual and team-based activities (tillage, harvest, etc.). Substantial raw materials were collected fromsuch contexts. Discussions were also held with local elders on thematic details when needs arose. Tape-recorder, video camera, photo camera, were used intensively along with stationery materials.

Sample analysis is devoted to discussing selected texts. As Burton (2000:307) observes, 'For practical reasons researchers are not always able to undertake a census and therefore need to take a sample drawn from a relevant population.' In this paper, too, sample analysis is aimed at making further inquiries on specific texts. Though there are plenty of literary texts related to the research topic, it is not manageable to make a-full-scale analysis of each item in a single paper. Therefore, it has been appropriate to select some representative texts from the bulk.

In this study Bailey's (1994) a 'three-level-sample screening' model is adapted. Bailey designates, first, the 'universe'. Second, he recommends a 'subset of some predetermined size from this population', the 'sampling element or units of analysis'. Lastly, he suggests a re-examination of whether or not these representing subsets adequately characterize their corresponding population. 
Likewise, in this research it was important to specify the 'universe'- the folk literature. The universe, yet again, was re-grouped into thematic entities. It was from these sub-divisions that some representative texts were drawn. Though the principal concern was to find out as much meanings of verbal texts as possible and to see their psychosocial implications on peasant views, the analysis, at most of its initial levels, has to describe the basis of the literary features as well. Then, interpreting the essences of unified themes followed employing eclectic approach.

The Study's Context of Intimacy and Integration

According to Miller (1984), analytical knowledge implies knowledge based on a proposition about truth. The potential meaning of things or their implication is arrived at after making further observation. As a result, it is improbable to deny the truth though the issue or its features are not directly revealed. Peasants of the Arsi-Robe have a remarkable knowledge about the impact of intimacy/integration on peasant economy and social security. But this knowledge is not directly revealed; rather one can detect it by analyzing the potential clues or symbolic representations.

The two concepts are intimacy and integration which are similar but different in scope. In the context of this study, intimacy refers to human attachment and interaction that occurs among individuals or small group members, like siblings. Integration is used to designate a social entity that comprises a bit broader size of population as compared to that of intimacy. 
As it is evidently observed in the context of Robe peasant community, both levels of attachments are very important particularly in the socio-economic and socio-cultural realms. Consequently, peasants seek different folkloric ways that enable them to organize their knowledge, labor, and other local resources in terms of intimacy and integration.

Implication of Intimacy in Kinship and its Physical Attractiveness

In the case of Robe wäräda, one can observe that people have centrally governing principles that guide individuals to behave, interact and conduct themselves in accordance with the collective code of conduct set by conventional rules. Individuals or local groups have duties, responsibilities as well as native rights based on local conventions that constantly nurture the customary principles. They involve participation of every member in every instance of aläminamäkära (Afaan Oromoo: gammachuu fi gadadoo) ${ }^{1}$. People are morally obliged, internally motivated and socially imposed to play their respective roles, in the affairs of an individual or groups ranging from happiness to tribulation. Consequently, individuals or groups form and share varieties of lore that informally connect members and enable them to maintain intimacy and integration both within and outside the folk group.

These central roles and conventional rights are introduced and inculcated in the minds of children, as a form of analytical knowledge, starting from their early age. The family in general, the family-heads in particular, play the initial role to create, establish and transmit the basic essences of traditional values and their native origins using all practicable techniques and strategies. Parents are culturally responsible to help their children recognize and practice the values such as respect for elders, tolerance, honesty, straightforward conduct, helpfulness, generosity and other virtues in the family using siblings or other closer people as

\footnotetext{
${ }^{1}$ Happiness and tribulation
} 
role models for demonstration in order to cultivate intimacy and, ultimately, integration starting from the small-scale social stratum, viz. the family.

Fathers, particularly, take the significant share in shaping the behavior of grown-ups. The implications drawn from the following forms of sayings (proverbs, aphorisms or idioms) may illustrate the responsibilities of family-heads (usually of fathers) regarding the good or bad behavior of their children and other youngsters.

Table 1: Implication of intimacy in kinship

\begin{tabular}{|c|c|}
\hline Sayings with themes of appreciations & Sayings with themes of criticism \\
\hline $\begin{array}{l}\text { Úa }^{a} 3 / \mathrm{U}^{\mathrm{a}} \mathrm{MI}:: \\
\text { A decent child from a decent family. }\end{array}$ & $\begin{array}{l}\text { —“<"SÖ }<\text { ÁN__MĐ } \\
\text { SKM-SKM ÁK< }<\text { "Å Ue` }:: \\
\text { There they come youngsters of my country; } \\
\text { Like reed plants, }\end{array}$ \\
\hline $\begin{array}{l}\text { eT@"• eÖ^KI/• eÖ]ÁKi:: } \\
\text { You make me famous. }\end{array}$ & 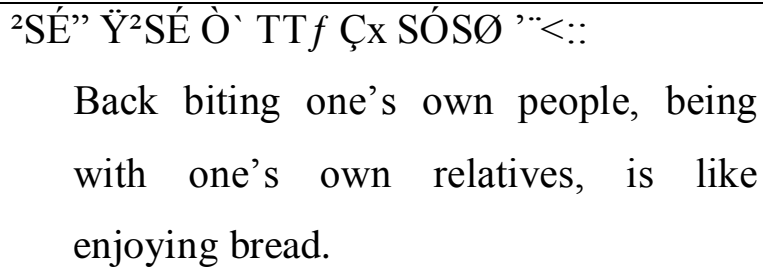 \\
\hline $\begin{array}{l}2^{`}{ }^{*} \times \mathrm{K} f::^{{ }^{`}{ }^{*} \times \mathrm{K} f::} \\
\text { He begot many children; His children } \\
\text { become prosperous. }\end{array}$ & 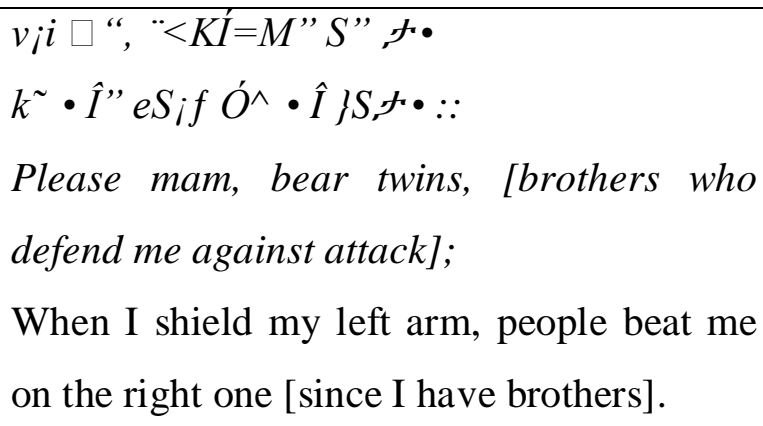 \\
\hline
\end{tabular}

From their informal learning (folk knowledge) people of Robe come to know that these kinds of verbal arts highlight the significance of family role in creating socially, ethically, and morally responsible members in the group. Carrying out responsibilities properly (the intervention) in social and cultural contexts reinforces people to have a close- 
knit contact with their own people. This tendency in the meantime becomes one of the important factors in various forms of cooperation and mutual understanding.

The community has to do with nurturing its social members. This takes place especially as growing-ups to spread out their contact across the socio-cultural setting. Especially elders play the leading social and cultural role in promoting and encouraging community manners and, side by side, reproving deviants or behavioral disorders in the young people. Elders take these local responsibilities and make efforts to maintain them because they have the fear that blame may come (from other neighboring communities) to them for they lack skills of shaping personalities of growing-ups very properly. Such sorts of criticisms usually fall upon the community particularly when outsiders observe their misbehaving youngsters on certain local occasions. The following may show how the community is critically concerned with personal qualities and local skills of its growing-ups.

$$
\begin{aligned}
& \text { ^—“<" SÖ }<\text { ÁÑ_MĐ } \\
& \text { SKM-SKM ÁK< } \square \text { "Å Ue`‘:: }
\end{aligned}
$$

There they come youngsters of my country;

Like reed plants, tall, slim and attractive they are!

Likewise, the following couplet illustrates the concern of a community about the skills of its members.

\author{
Ñ.eUd \}MÊ ÁM²’’ MÏ

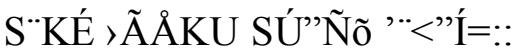 \\ He who is not a good singer, being a Gädämisa²-born; \\ He is not born; but aborted.
}

\footnotetext{
${ }^{2}$ Name of a local place in thewäräda
} 
Here the central issue will be: What kind of peasantry-related realities force or reinforce peasants to create and cultivate intimacy and local integration through their folklore. The discussion below attempts to address this question.

Folk Knowledge about the Need for Integration

According to Foster $(1965: 294)$ peasants 'look upon themselves as powerless'. They feel that it is difficult for them to break their customary patterns and come to a new tradition. Thus, they constantly live in uncertainty. In order to minimize the intensity of their fear as well as to reduce the possible adverse effect of natural and human threats, they establish a strong social structure that serves as an important local security mechanism. In this social structure two relations receive attention: kinship and patron-client relation (ibid). Both patterns eventually induce social integration in the peasantry. Folk knowledge encourages the community to foster close-knit contacts at family as well as at community levels. This knowledge can be viewed from social welfare and economic peasant perspectives as discussed below.

\section{Social Security from Peasant Perspective}

Human relation in the peasantry differs from the city lifestyle for many reasons, one being the need for both the psychological and physical closeness to one's people. As one can observe the close-knit social contact is understood as the means of social security. People have a dominant belief that their well-being, mental stability as well as their economic life are determined by the size and the condition of wägän (Afaan Oromoo: lammii ${ }^{3}$ ) they have. It is quite important to notice here that even the deep connotation of the term hagär (Afaan Oromoo: biyya, meaning acountry) depicts the full meaning of one's attachment to residential

\footnotetext{
${ }^{3}$ To mean one's own people, chiefly relatives
} 
vicinity or the region of one's kinship. Look at the following verbal lore to confirm how this argument has a factual basis.

Verses depicting the bitterness of loneliness

$$
\begin{aligned}
& v_{i} i \square “, "<K I=M{ }^{\prime} S^{\prime} ”
\end{aligned}
$$

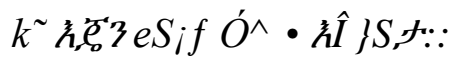

Please mom, bear twins, [brothers who defend me against attack];

When I shield my left arm, people beat me on the right one [if I have no brothers].

$$
\begin{aligned}
& \text { "Ñ_ } \\
& \text { ÏÓU >MŸó ÅeU >LK }
\end{aligned}
$$

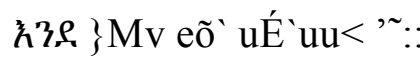

Displaced I am from my native place, and in a foreign locality;

Neither am I very saddened nor happy;

I feel self-incompleteness.

Likewise the following proverbs depict the significance of tolerance among relatives

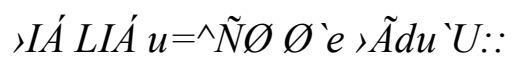

Donkeys never lose their teeth for they kick each other.

$$
{ }^{2} \text { SÉ” Y̌²É Ò` TT } f \text { Çx SÓSØ }{ }^{\prime \cdot}<::
$$


Back biting one's own people, being with one's own relatives, is like enjoying bread.

The above proverb depicts a theme of tolerance using donkeys and their quarrel as symbols. Donkeys often fight and one donkey may kick the other violently on the chin. But the blow does not cause any serious physical damage no matter how it is vigorous since the physiological structure of donkeys can naturally enable them endures such blows. Similarly, any disagreement occurs between people from the same family background could be resolved without causing further social crisis since they tolerate each other or as long as they have developed similar psychological makeup.

The verbal texts above, directly or indirectly, reflect that there is social insecurity. It should be that people suffer from absence of peace, health problems and economic constraints, etc, which make them aspire perpetual mutual support from their own fellows.

The basic reason for lacking sustainable peace may be seen from different viewpoints. As it could be observed from local experiences and from the implications of the data collected, the general condition of peace-keeping service seems unreliable because of its low standard. The government carries out its peace-keeping duty using Birkiis ${ }^{4}$ as peace-keeping agents. There is also a form of local council called firdshängo (Afaan Oromoo: abbaa murtii), a decision-makingbody at the qäbäle level. These peasants have neither knowledge of law, legality and security principles nor any form of training. They investigate legal proceedings using very conventional and cultural procedures. Moreover, dwellers do not keep trust in some of the birkiis and members of the council itself since they are thought to abuse their responsibilities. The existing legal service and practice, therefore, has a tendency to frustrate the local people as far as safety-keeping services are concerned.

\footnotetext{
${ }^{4}$ Birkii are peasants elected from the community and assigned, in their own neighborhood, as local peacekeeping agents receiving no training and no incentives for their service.
} 
The second, probably the wide-ranging reason for uncertainty regarding peace, could be the lower level of awareness that the community maintains about self-defense and legality. This is usually reflected in controlling lawlessness or in conflict-handling traditions. Though there are significantly valuable local trends that enable the community sustain local security, some of the mechanisms employed in handling conflicts rather worsen security conditions and lead to somewhat hostile social disorders. When people quarrel they become nervous and mostly commit verbal or physical offense or both. But they no longer understand that they are in a condition of lawlessness due to their low awareness about law. Rather they might take their attack as an act of bravery or assume themselves as persons with best human quality, wänd (Afaan Oromoo: dhiira, literally means manly which connotes bravery or gallantry) as the following text suggests this shared tendency.

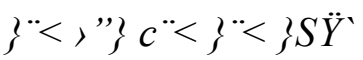

$$
\begin{aligned}
& \text { ڤ३P. } \square S Y ́ f g T u A U U d f^{\prime} \ddot{Y}: \because
\end{aligned}
$$

Take care you guy; you should better be advised;

Otherwise you will be soaked in blood [that your own body sheds when stabbed].

People quarrel for various reasons, mostly economic. They aggressively beat each other up. Other people rush and intervene between the two quarreling individuals and they stop the fight, making some possible effort they could do, in order to minimize the degree of social chaos or extended injury or potentially occurring physical and social damage. Such an intervention is a form of social responsibility. Then the case is immediately taken to shimagles, traditional peacemakers. Conflicts would be resolved customarily, with the greater efforts of the shimagles. 
One should appreciate such a conflict-handling folklore practice since it serves at least as a tentative problem-solving mechanism. However, the shimiglina (Afaan Oromoo: jaarsuuma, meaning peacemaking system) has its own defects too. Primarily, it does not enable people to be introduced to fundamental human rights and legal systems. Besides, in several cases the reconciliation does not enable people to root out the causes of conflicts through legal procedures and restore sustainable peace among individuals. Conflicts relapse again and again on the same issue and shimagles become usually busy with settling disputes arising on similar matters.

Since the existing customary conflict resolving system appears to be deficient in handling serious cases, related to land and land-holding systems, people tend to defend attacks through physical fights. Counter attack, vengeance, and hatred may become constant among individuals. In the meantime, disagreements broaden their scope and the magnitude of conflicts grows more intense. Mutual respect suffers; peace is challenged; life is, thus, jeopardized.

In such social context the presence of a large size of wägän becomes the significant source of self-defense or a means of maintaining security or power equilibrium. The following oral poems illustrate this situation.

$$
\begin{aligned}
& \text { Öõ×ó É’’̀̀̃ SkSÝ }{ }^{, \cdot .<}
\end{aligned}
$$

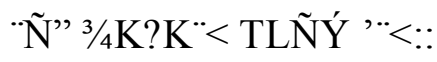

A flat stone serves as a seat;

A kinless person is the one whom people mock at.

To sum up, the knowledge people acquire concerning the essence of social security in general and their welfare in particular, underlies their collective mentality that signifies proximity, closeness and integration are quite important to ensure one's welfare. It is this collective mentality that gives rise, in turn, to other psycho-social tendencies exhibited in a 
variety of folklore forms that promote social attachment, of them kinship, kin-like relation and settlement being prominent.

Economy-related Perspectives: Unity from Occupational Point of View

Arising from this fundamental local knowledge, peasants try to make necessary economic intervention using the folkloric work cooperation mechanisms. Both aforementioned devices help them form and cultivate favorable attitudes toward their folk group in general and certain social entities in particular in their social context. This indicates, in a broader sense, how peasantry is integrated with socio-economic and socio-cultural contexts. In addition, it also indicates how peasants understand and define the essence of social integrity and its role in withstanding the effects of unfavorable natural phenomena on the subsistence economy (Hedstrom, 2005).

Intimacy or social cohesion gives an essential meaning to economic life of peasantry in general. This is true also to Robe small scale farmers at least for a fundamental reason: they define it from their occupational point of view.

As Sahlins (1972) observed, peasantry is by and large characterized by a high degree of labor utilization and by tedious work traditions. Due to the fact that the production system is not mechanized, peasants are compelled to invest massive human labor to obtain better yield. Furthermore, in a peasant context like Robe, for example, subsistence production is frequently exposed to or challenged by climatic inconsistencies and weather vagaries. Unless peasants make timely intervention between the crop life and weather hazards; or unless they cultivate their lands during the ideal time of tillage, through intensification of labor input, they know that substantial production losses would follow and, as a result, their families would suffer from food shortage. 
These fundamental peasantry conditions increase the need for harmonization of human knowledge, skills and local logistics which necessitate favorable social and cultural environment that is only realized by special proximity, social cohesion and group integration. In other words, in order to keep themselves viable in the intensive peasant labor system, peasants know that they must allocate optimal labor input especially during demanding ploughing, weeding and harvesting months. This communal impression can be explained better with the help of two important occupational folklore traditions locally called däbo and wänfül.

The local work traditions däbo and wänfäl which are two customary devices, as components of occupational folklore, not only suggest the significance of strong intimacy and mutual support in economic sphere, but they also show the knowledge and attitude the community maintains concerning the productive aspect of team work.

Däbo (its local synonym jigi) refers to a communal labor force assembled to accomplish a given type of work like harvesting crops, ploughing activities, building of houses and any such similar tasks within a day. It is a form of customary lore that implies how peasants are aware about the implication of labor cooperation for boosting productivity and fostering social ties in the community. Däbo has a greater meaning to production process particularly during the period of peak labor demand for tasks like completion of weeding, harvesting etc. It usually involves a relatively large number of people and is a large-scale form of work cooperation in the area. In short, it is used when massive labor input is required.

The family (the owner of the project) uses a direct or an indirect way to make the request for such work assistance. The direct request is made by the family itself. A member of the family, usually the family-head, goes around the neighborhood and asks fellow men that s/he thinks willing to assist her/him in accomplishing the work intended on the appointed day. Here it is proper to remind that the number of helpers a person obtains is determined by 
her/his the social acceptance s/he secured in the community. Agreeable manners a person has a lot of assistance s/he obtains and vice-versa. This indicates that jigi is not an obligatory commitment; rather it is a manifestation of closeness and friendship.

The indirect one is locally known as ras-simosh (Afaan Oromoo, waleessaa). This däbo assembling commitment is carried out by a person outside the family concerned. But the person could have closer kinship or matrimonial attachment with the family that desires the assistance of the däbo team. The labor assembling task, limäna (Afaan Oromoo: kadhaa), to mean request for $d \ddot{a} b o$, is usually carried out by sons-in-law to parents-in-law.

Däbo or jigi creates a favorablework context since it is accompanied by certain features that stimulate deep interests in the occasion itself. People consider it as the most motivating occasion that increases endurance and makes the work surprisingly pleasurable. In many cases it is regarded as a source of enjoyment. The family prepares a big feast for the team, the helpers. Splendid type of food and local alcoholic drinks, täla and katikala, are served, plentifully. Especially handing round the alcoholic drink keeps on starting from the late-morning-hours of the day to the late evening hours, on the occasion of the work and during the time of rejuvenation as well. The family entertains the participants preparing a post-work get-together as well. The following Amharic poem performed on such occasions indicates that the family would prepare an extensive meal for the get-together held in the evening.

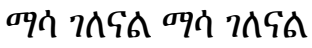

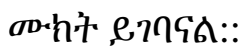

We killed the farmland, we killed the farmland; [we accomplished the task]

We deserve hence a fattened sheep/goat.

The overall conditions invite participants to chat excitedly. The comical conversations, teasing, mockery, etc., that the participants make have a greater impact on 
motivating work interest and reducing feelings of physical fatigue. Songs are the prominent accompaniments on the occasion of däbo. The songs may reflect on the value of mutual help and mutual integrity as well; or invoke some nostalgic themes related to love, patriotism and so on.

In däbo songs there is usually a lead-singer who initiates the interest for singing. The remaining participants collectively respond to the recitation with a group chorus. It can be noticed here how the songs could play essential roles to minimize boredom and, on the contrary, to stimulate mental acuity.

Däbo is not only a device in enhancing work efficiency, but it also plays a key role in creating new social connection as it presents more opportunities for mutual understanding and extended friendship. This is in conformity with what Velsen (cited in Peck and Y 2004: 54) says: 'The closer the interacting units live together, the more frequent and varied the contacts'. The tradition also induces work culture because of the fact that participants have wider access to exchange feedbacks concerning their work skills and efficiencies. It is also an important scenario in which people can share peasantry-related knowledge and local information.

The folkloric means, däbo, requires economic capabilities (like having more grain stocks) to prepare a big feast; and it is also correlated with the degree of social acceptance the family maintains since it is a kind of labor service received from closer people expecting no visible immediate return.

However, those who cannot afford food and drink for the expected extensive feast and lack strong social basis may go for another option: wänfäl. Wänfäl is a small-scale form of work cooperation as compared with däbo. It is a regularly occurring form of mutual support that could be regarded as a labor exchange system. A person devotes his full day time, from dawn to dusk, working on his friend's field expecting that he will receive similar help from 
the same workmate. The other person, who is indebted to the labor input, goes to help his friend in the repayment of labor input devoted during the previous day. In wänfäl tradition each coworker is morally compelled to satisfy the labor need similar with the assistance he receives from the person concerned. Wänfäl usually involves two or three people. The coworkers in the smaller team work together on one of their friends' field. The process continues until every group member pays the labor debt back to his colleagues. Unlike däbo, in wänfäl the family is not expected to prepare an exaggerated feast; only a single meal (lunch) and a bottle of katikala suffice.

On the whole, the whole conditions of work collaboration, be it däbo or wänfäl, and the accompanying atmosphere exhibits the critical need for locally organized social cooperation and folk group integration in the context of Robe peasantry. From the above accounts of däbo and wänfäl, in general, it can be stated that peasants in the area have some observable knowledge concerning: (1) the relationship between the subsistence agriculture and the local environment in the sense that they try to tackle all hazards resulting from weather related disasters or other forms of problems that cause subsistence failure; and (2) the strategies they should employ to alleviate labor deficiencies; that is why they have created and maintained coping mechanisms like däbo and wänfäl. Here their better perception of their world is manifested in their understanding that labor increases productivity that the family hopes to attain.

Collective Attitude in Social and Spatial Relations

In the foregoing sections, it has been indicated how human interrelationship and integration are significant in social welfare and labor cooperation in the community concerned. Thus the people do their utmost to create and amplify manifold possibilities to 
attain team spirit and solidarity. Social and Spatial Relations, discussed below, may be described as possible ways of attaining personal intimacy and group integration.

\section{Elements of curse: Ox, neighbor, wife and son}

These things are employed considering their socio-economic and intimate relations. They significantly touch upon the knowledge and attitude the community maintains with regard to $o x$, neighbor, wife and son. The community also understands, as it learns from its customary knowledge, what these things mean to a wicked person.

The ox is the main basis of subsistence and wealth; source of food (particularly for feasts prepared on special occasions and holidays) and source of hide and leather for household materials such as sleeping mat, loading strap, etc. On top of these, the ox is the decisive labor force. An evil ox does mean, therefore, nothing but a cause of limitless crisis in all aspects of economic life.

The neighbor, being one form of social institution, at the lower level of social network, connotes close-knit human relationship in terms of residence. Neighborhood could be considered as an indicator of intimacy and, side by side, a co-operational local agency in securing social welfare and peaceful co-existence. Furthermore neighbors offer mutual help during hard-times, alämna mäkära. In many areas of Robe there are age-old customs and traditions that reinforce people to organize themselves at this level of institution and establish sustainable harmony so as to manage natural and man-made disasters and maintain peaceful co-existence.

But if neighbors are not in good terms there is always a chance of attacking one another as the Amharic proverb suggests 'Fire arises from home and attacks the household itself; and, similarly, enmity harbors in the neighbors'. The father used this narrower social division as his material of curse to emphasize this general theme.

Marriage is an important form of social fusion, in Robe, which constitutes the basis for nuclear kinship. As a result, the emotional attachment between husband and wife is thought to be 
very strong and positive. This is depicted in Amharic proverb 'A husband and a wife are drawn from the same wellspring'-this is to mean, the couple has similar personal behaviors and internal qualities by nature.

However, this collective view, depicted in the proverb, sometimes remains merely an ideal motif. One can objectively observe the fact that couples may have mismatching, if not contradicting, personal qualities, which sometimes cause unfavorable conditions in the family as a whole. When wives happen to be bad-tempered, for example, husbands face dissatisfaction. The effect could be divorce, which results in additional social crisis, the worst one being the misery of their children. This induces a wide-ranging impact on the subsistence economy and social security motional harmony.

The father in the story chose the wife for his curse because he knew thoroughly what a nagging wife meant. She constantly digs out minor errors and complains on pointless issues, which makes the husband restless and uproar.

The researcher asked Badaadaa, one of his interviewees, some questions concerning the attitude of the community towards sons. He said that having a male child is highly valued. During their childhood sons serve their parents in many more ways than daughters do. They take herds to the pasture for grazing, which is rare in the case of daughters; gather firewood more effectively than daughters; and so forth. When they grow stronger, they are engaged in farming activities such as tilling the land, harvesting the crops, building huts, fencing compounds and the like.

Beyond their ability of physical labor, sons are considered as potentially and physically capable of providing protection for members of their family and as contributors to social welfare. Fathers and mothers, brothers and sisters usually rely on male children to be defended from any form of harm from others. A son is expected to avenge the injury that his father or brother would receive. Otherwise people mock at him calling him a coward. But the most significant factor for sons to be preferred to daughters is that they look after their parents in their old age. This is because ideally 
sons have more opportunities for special proximity to their parents and play a decisive role over the properties of the family, which is not usually so in the case of daughters.

As a result, when a parent has a wicked son, the consequence will be grim. In other words deviant sons create feelings of dismay in parents, even in the community as a whole, which is contrary to the usual expectation. This is assumed to be true especially when a father curses his son. As illustrated in the narrative, the mythical knowledge tends to confirm that a father's curse is transmitted from generation to generation. This impact of accursed sons, in turn, extends, in due course, its negative effect to the community as a whole. Therefore, the misfortune does not stop with the son unlike it happens in the case of an ox, a neighbor or a wife. Its damaging effect leads to inherited social disorders, at the family as well as the folk group levels. The matter is terrible and inescapable as it is suggested in turn taking 42 of the narrative.

The narrative elements selected (Ox, neighbor, wife and son) are arranged, in an ascending order so that they enable the narrator to produce a special sense of literary effect. The literary effect of the arrangement arises from depicting the magnitude of the character's (the father) internal situation as it goes from bad to worse. Ox, neighbor, wife and son are introduced in this order to amplify the thematic seriousness. In a story recounting, the order shows change and development of emotions of the father, starting from the orientation level, “...a son did wrong to his father...' (turn taking 4) to the denouement of the story, 'Oh, father, you found an inescapable curse now' (in turn taking). The emotional condition of the father lies between anger and frustration. The sum total of the situation involves annoyances (due to the son's initial disobedience), anger (at the response given by the son to the first curse), shock (owing to the impertinent reply for the second curse), bitterness (due to the interminable misbehavior of the son) and frustration (because of the father's inability to reprove his own son). 


\section{Ending Technique}

The narrative ends with the anticipated failure of the antagonist, the son. Such a technique is one of the prominent folkloric narratives. It characterizes the moralistic force of oral narratives in general (Hoko and Voight, 1980: 24). In folk narratives characters that deviate from the culturally valid norm are made to find themselves in unbearable trouble and in sorrowful conditions. This is clearly revealed in the narrative. The deviant son, received severe punishment. And, ultimately, he has sensed it. He could not escape it as he did in the remaining three curses. He felt anguish and humiliations for his own misbehavior. The final change in of the son, therefore, is highly significant as it leads to the impressive and meaningful denouement of the story.

It seems proper to assume that the son became sad for certain reasons. It is indirectly disclosed that the curse would fall upon him. If he had the courage to ignore the curse taking it, for example, as a mere superstition, he would not have been worried by its estimated damage and should not have replied as, “...Woe, father, this is a horrifying curse.” (in turn taking). He might have, one may make a simple guess, learnt in his empirical experiences that people of bad destiny in the community ascribed their misfortunes to paternal curses, when they face occasional tribulations. On the other hand, any father of a rude son is, usually, condemned in the community, as implied in the earlier discussions. The reason is that, according to the view of the community, rudeness results from poor handling during childhood. If misbehavior is exhibited in a family, it is not the mother or any other family member that deserves the blame, but the father. The son is criticized $3 / 4 c$ ? $f \ddot{I}$ ( $a$ woman-fostered son, to mean vulgar, ill-mannered).

As the story illustrates, the father successfully changed his rude son. This is so because the ending technique foregrounds the moral that modest, tolerant and observant people achieve their final goal whatsoever challenging elements confront them. This should be one of the ways that such collective moral themes, concerning iniquitous sons, are embedded and manifested. The implication 
is that let alone virtuous people even wicked ones fear and hate ill-mannered sons owing to their damaging effect on the coming generation and the community as a whole.

\section{Conclusion}

In this study an attempt has been made to examine how human beings are influenced by folklore in peasant setting in terms of knowledge and its recurrent results, attitude and intervention. Knowledge is a cognitive competence that enables an individual or a group to grasp information and form an integrated memory repertoire about things in the life. The analysis shows that peasants have knowledge, even if it is well-utilized, concerning both 'the natural phenomena' and 'the facts of social life'. Furthermore, peasants critically understand the correlation different aspects. The socio-cultural, socio-economic and psychosocial facts, embodied in the folklore, highlight that peasants have informally learnt and customarily developed local knowledge. This kind of knowledge could be acquired through 'undergoing the consequence of what has been done' or experienced. Thus it could be designated as a latent or passive form of knowing about the social and natural environment. Such form of knowledge is classified as a traditional knowledge; i.e. knowledge 'passed down by word of mouth' and practical intervention. 


\section{References}

Bailey, D. 1994. Methods of Social Research: $4^{\text {th }}$ Ed. New York: The Three Press.

Bauman, R. 1986. Contextual Studies of Oral Narratives. Cambridge: Cambridge University Press.

Bronner, S. J. (Ed) 2008. The Meaning of Folklore: the analytical essays of Alan Dundes. Logan: Utah State University Press.

Burton, D. (2000). Research Training for Social Science. London: SAGE Publication Ltd.

Fisher, A. 1991. Structure of Social Life: the four elementary forms of human relations. New York: The Free Press.

Fiske, A. (1991). Structure of Social Life: the four elementary forms of human relations. New York: The Free Press.

Foster, G. (1965). Peasant Society and the Image of Limited Good. American Anthropological Association, 67(2), 293-315

Hedstrom P. (2005). Dissecting the Social: On the Principles of Analytical Sociology. Cambridge, UK: Cambridge Univ. Press.

Hedstrom P, Swedberg R, eds. (1998). Social Mechanisms: An Analytical Approach to Social Theory. Cambridge UK: Cambridge Univ. Press.

Hoko, L. and Vilmos Voight (ed). (1980). Genre, Structure and Reproduction in Oral Literature. Oxford: Oxford University Press.

Miller, D.1984. Question that Matter: introduction to philosophy. New York: McGraw-Hill Book Company.

Oring, E. 1992. Folk groups and Folk Genres. Logan: Utah State University Press.

Peck ,M. and K. Yankah (eds). 2004. African Folklore: Encyclopedia. Newe York: Routledge book, Inc.

Sahlins, M.1972. Stone Age Economy. Chicago: Aldine Press. 
Sims, M. C. and M. Stephens. 2005. Living Folklore: an introduction to the study of people and their traditions.Utah: Utah State University Press.

Suter, J. (ed.) 1994. Working with Folk Materials in New York State: A Manual for Folklorists and Archivists. New York: New York Folklore Society.

Wilson, A. (2006). The Marrow of Human Experience: Essays on Folklore. Utah: Utah State University Press. 